\title{
PLURILINGUAL COMPETENCE, STYLES AND VARIATION
}

\author{
Jyrki Kalliokoski \\ University of Helsinki
}

\begin{abstract}
The paper explores plurilingual competence in respect to language proficiency, language education and pluri- and multilingualism. The notion of communicative competence was introduced by Hymes (1972) as a reaction to chomskyan view of language as an autonomous system. Hymes' notion of communicative competence originally included plurilingualism. The concept of communicative competence was quickly adopted to applied linguistics but the idea of a linguistic repertoire consisting of the competencies of linguistic varieties was not imported to SLA or language testing. The Hymesian perspective to plurilingualism as an essential dimension of communicative competence was revived in the Common European Framework (CEFR). However, the practice of applying the CEFR has mostly neglected the dimension on plurilingualism and plurilingual competence. The focus in the use of the CEFR has been on the different areas of language skills within one single language at a time, while the application of plurilingual practices has gained very little attention. The Hymesian notion of communicative competence has lived on in the sociolinguistic research tradition, especially within interactional sociolinguistics. The present paper relates the notion of plurilingual competence to its hymesian origin, to recent trends in plurilingual and pluricultural education, and to the sociolinguistic study of style and linguistic variation in multilingual communities. The article uses Finnish L2 data to show how plurilingual competence is used as an interactional resource. From the perspective of language learning, plurilingual competence enables speakers with different linguistic backgrounds to use their shared linguistic repertoire in order to ensure smooth interaction and achieve mutual understanding.
\end{abstract}

Keywords: communicative competence, plurilingualism, language teaching, interaction 


\section{Introduction}

In 1972, in an article ${ }^{1}$ entitled On Communicative competence, Dell Hymes launched the concept of communicative competence, which refers to the human capacity to use language in social context. This text by Hymes was a reaction to Chomsky's transformational grammar as presented in Aspects of the Theory of Syntax in 1965. Chomsky states a programme for autonomous linguistics, and presents the famous dichotomy competence performance. For Chomsky, the only proper object of study is the linguistic competence of an ideal speaker-listener. Chomsky's model therefore ignores the social dimensions of language, language in use, the relationship between language and context and language and social action. And, like most linguistic theories, it is a strictly monolingual model of language (structure). Hymes challenges Chomsky's view of autonomous language competence. Furthermore, Hymes does not make a division between first and second or foreign languages. Instead, he presents speakers of different kinds of linguistic backgrounds as cases to illustrate the notion of communicative competence. These cases also include speakers who in the 1970s would have been labelled as semilinguals. Hymes portrays a plurilingual - or in his terms, a multilingual - person as a counterbalance to Chomsky's ideal monolingual speaker-listener: "There are tribes of the northeast Amazon among whom the normal linguistic competence is a control of at least four languages [...] Here, as in much of our world, the ideally fluent speaker-listener is multilingual" (Hymes 1972a: 274).

This article proceeds in the following manner: I will first discuss Dell Hymes's notion of communicative competence in respect to plurilingualism. I will then explore the use of this concept in applied linguistics and the role of communicative competence in the Common European Framework for Languages (CEFR). After this, I will change my perspective to the study of multilingual communities and to the idea of plurilingualism as a resource for interaction. Towards the end of my article, I shall illustrate my ideas with examples from Finnish L2 data.

${ }^{1}$ This article (or actually an excerpt from Hymes's monograph with the same title) was published in a volume entitled Sociolinguistics which was edited by Pride and Holmes. 


\section{Communicative competence and applied linguistics}

Hymes's notion of communicative competence gained much attention both in sociolinguistics and in applied linguistics in the 1970s and 1980s. Since then, his ideas have travelled across disciplines and the notion of communicative competence has repeatedly been adopted by several scholars in different contexts. This notion was introduced in the field of second language acquisition by Canale and Swain in their seminal article (Canale and Swain 1980, see also Canale 1983). They elaborated Hymes's idea of communicative competence from the point of view of language learning, teaching and testing. Canale and Swain also refer to Campbell and Wales's (1970) use of the term communicative competence when trying to adjust Chomsky's dichotomy to second language learning. Campbell and Wales, however, concentrate more on the psycholinguistic aspects of the competence - performance dichotomy and comment very little on the social dimension of language that was essential to Hymes's original notion of communicative competence.

Canale and Swain divided the notion of communicative competence into three (sub)competencies: grammatical, sociolinguistic and strategic competence. They presented a very influential programme for language teaching and testing which emphasizes the importance of meaning versus form in language education.

The version of communicative competence by Canale and Swain was then quickly adapted by Bachman in the realm of language testing. In his book Fundamental considerations in language testing (1990), Bachman offers a more taxonomic approach to the concept of communicative competence (or, as he calls it, language competence). According to this approach, the different components of communicative competence are neatly organized into a hierarchical tree-diagram, consisting of organizational and pragmatic competences, further divided into grammatical and textual competences on the one hand, and illucutionary and sociolinguistic competences, on the other hand, and even further to 15 different sub(-sub)components. Since then, 
Bachman's taxonomic model has dominated the field of applied linguistics, or at least language testing. ${ }^{2}$

After these influential models of language proficiency presented by Canale and Swain and Bachman, there has been no end in attempts to apply the notion of communicative competence in language education and testing. The very part which distinguishes Hymes' notion from Chomsky's competence, in other words the communicative competence minus language structure, has represented a major challenge for the different models of communicative competence in the framework of second language acquisition studies and research on language testing. The solution for this varies from scholar to scholar, as does the way this concept is implemented in teaching and testing or when presenting language policies of different sorts, in various contexts. What seems to be the core of this what-once-was-Hymesian concept is the following: language (proficiency) is something more than (just) grammar and vocabulary.

While the notion of competence was rather quickly established in the core of applied linguistics, one important element in Hymes's view of communicative competence got washed away when it was first imported to applied linguistics: the multilingual individual and his/her varying linguistic resources. As I already mentioned, Hymes underlines the significance of an individual's linguistic resources, knowledge of different languages and styles, also within one single "language". In fact, he encourages us to put the word language within quotation marks:

[---] if one analyses the language of a community as if it should be homogenous, its diversity trips one up around the edges. If one starts with analysis of the diversity, one can isolate the homogenity that is truly there. (Hymes 1972a: 276.)

Canale and Swain and their followers advocate the communicative approach to second language teaching and testing, and they pay attention to the classification of the different social

\footnotetext{
${ }^{2}$ This componental view on communicative competence could in part be traced back to Hymes's seminal model of the speech situation (Hymes 1972b), consisting of the following components or contextual variables: message form; message content; setting; scene; speaker/sender; addressor; hearer/receiver/audience; addressee; purposes (outcomes); purposes (goals); key; channels; forms of speech; norms of interaction; norms of interpretation; and genres ( = S-P-E-A-K-I-N-G).
} 
and situational features of language use in context. But they depart from Hymes's original idea in one essential point: their view of communicative competence is predominantly monolingual. Furthermore, Hymes's idea about putting "language" in quotation marks, which emphasizes linguistic variation and breaks the illusion of a homogenous language, is not really visible in Canale's and Swain's or Bachman's later versions of communicative competence.

\section{Plurilingual competence in Common European Framework}

One of the fundamentals of Common European Framework for language learning, teaching and testing (CEFR) is the idea of a multilingual individual with varying skills in several languages. The document uses the term plurilingualism. This notion of plurilingualism, i.e., multilingualism on an individual (micro) level, is presented in the beginning of the document, and after this, it appears in the text from time to time. Sadly enough, the plurilingual perspective mostly tends to disappear among the numerous definitions and descriptions of the different sub-areas of language proficiency in the CEFR document. The CEFR is abundant with series of taxonomies and can do-tables. Although the authors warn the reader not to take these descriptions and categories as fixed or exhaustive, one is tempted to say that their abundance is at the least exhausting. The resulting picture of competence is formed by the lists of abilities and activities.

The notion of plurilingualism in the CEFR is linked with individual's varying competence in different languages, the idea of partial competence. This approach is very much akin to Hymes's view of communicative competence. According to the CEFR, an individual's different kinds of competencies in different languages - L1, L2, L3 etc - form his/her linguistic repertoire.

The CEFR is currently widely used in the educational systems across our continent and outside Europe, as well. It is applied in schools, university language centres, and in language testing both in pedagogical contexts and in working life. It is used to enhance language teaching and to develop an assessment of language proficiency - but it is predominantly used only for one language at a time. 
This is not what the developers of CEFR originally had in mind. One of the authors of the CEFR, Daniel Coste and his colleagues published earlier a preparatory paper (Coste et al. 1997) where they clearly promoted plurilingualism and referred back to Hymes's original idea of communicative competence:

Whatever the original characteristics of the concept of communicative competence (Hymes emphasised the heterogeneousness of linguistic communities and individual competences), it has developed, as far as language teaching is concerned, according to the model of the ideal native communicator: the characteristics of communicative competence (as distinct from strictly linguistic competence) are the sociolinguistic and pragmatic abilities, knowledge and aptitudes of speakers who are implicitly assumed to be monolingual native speakers or who are at least regarded as functioning in circumstances of endolingual communication (i.e. communication involving persons deemed to have a perfect, homogenous knowledge of the resources of the medium used, namely their first language). The goals of learning a foreign language, including the various threshold levels, fall short of this native-speaker competence; furthermore, the learner is not explicitly taken into account as a plurilingual subject (able, for example, to call on the resources of his mother tongue or of another foreign language of which he already has some knowledge). (Coste et al. 1997: 9.)

Coste, Moore and Zarate published their paper in 1997. As I have mentioned, part of their recommendations can be found in the final version of the CEFR but the monolingual ideal and compartmentalization of the teaching of different languages one-by-one still prevail in the CEFR - and a true appreciation and exploitation of individuals' linguistic and stylistic repertoire remain a neglected dimension in language education. As Coste, Moore and Zarate stated 12 years ago:

[---] it is also necessary to stress that the concept of plurilingual and pluricultural competence [---] has hardly any recognized status in current didactic thinking, any more than in pedagogical applications. (Coste et al. 1997: 11.) 
Very little has changed in 12 years. To my knowledge, there have been few applications of plurilingual approach to language teaching in Finland. For instance, the National Curricula for teaching languages at primary and secondary schools in Finland are based on the CEFR but thus far there has been no interaction between the curricula of the different languages. University language centres have also not had much offer in this direction apart from courses in Danish for speakers of Finnish, relying on the students' knowledge of Swedish or academic excursions to Switzerland promoting plurilingualism.

However, at least in the francophone world of scholars of bilingualism and second language learning, a strong tendency has emerged to promote plurilingualism in language education. Recently this tradition has been presented in The International Journal of Multilingualism (Volume 6, 2, 2009; see, e.g. the contributions by Lüdi and Py, Moore and Gajo). There is also a recent handbook on plurilingual and pluricultural education published in France and in the webversion at UC Berkeley (Kramsch et al. 2008). The writers of this handbook have focussed particularly on the role of teacher education. Kramsch and her colleagues (2008) see the didactics of plurilingualism/pluriculturalism as an intermediate phase. The real goal for them is what they call plurilingual and pluricultural didactics.

\section{Plurilingual communities and sociolinguistics}

It is important to stress that plurilingualism is not a new phenomenon but can be found in various multilingual communities around the world. Furthermore, plurilingualism has existed in different linguistic communities throughout history. In our present-day world, we are daily exposed to several linguistic varieties and often use several varieties even within one single social encounter. Plurilingualism is therefore a reality both in everyday communication and in various institutional and educational contexts.

While applied linguistics has continued to develop models for describing communicative competence or language proficiency in one language at a time, sociolinguistics has moved from traditional variation studies to the approaches which take into account more sensitively the language user's linguistic repertoire 
and the role of context (cf. LePage and Tabouret-Keller 1985). Gradually, monolingual approaches in sociolinguistics have given way to research traditions which take multilingual communities and multilingual individuals and contexts as their research objects (Blommaert 2010). Furthermore, interactional sociolinguistics and the sociolinguistic studies of style (e.g. Eckert and Rickford 2001, Auer 2007, Auer and Li Wei 2007) have met the challenge of plurilingualism and multilingual interaction. The founding father of interactional sociolinguistics, John Gumperz, is known as one of the most prominent scholars of code-switching and related phenomena (see e.g. Gumperz 1982, 1992).

Globally, increasing migration produces new multilingual communities especially in big cities, also in urban centers in the Nordic countries. The basis for a new kind of multilingualism is created by the migrants' new languages together with the linguistic varieties of the more or less traditional, already existing bi- and multilingual communities. Scholars of multilingualism and sociolinguistics have focused their attention especially on multiethnic and multilingual youth and their linguistic and sociocultural practices, because the youth tend to be innovative and adaptive to change. The numerous studies of the urban young people with linguistically and culturally diverse backgrounds in different contexts (Rampton 1995, 2006, Keim 2007, Deppermann 2007, Qvist and Jørgensen 2007, Jørgensen 2005, Lehtonen 2006, 2009, forthc.) have shown how plurilingual practices are being realized in these communities as a part of everyday communication. The linguistic repertoires of these young plurilingual individuals include the different varieties of their L1 and L2 as well as (global) English and other languages and linguistic varieties, and they use these varieties as their linguistic resources for interaction, both in their face-to-face conversations and in their interaction mediated by the Internet and mobile communication systems (cf. Androtsoupoulos 2007).

When we aim at understanding the linguistic practices of multiethnic youth, partial competence, also promoted by the CEFR, has a key role. The wide repertoire of languages and linguistic varieties used in one linguistic community and by single individuals does not imply that all languages are mastered at an equal level by one single individual. Instead, the implication is that elements of the different languages which individuals know are taken into use as interactional resources. As various stud- 
ies have shown, phenomena such as crossing, styling and the mock-use of another's linguistic varieties, and other manifestations of linguistic polyphony (or heteroglossia) in the sense of Bakhtin (e.g. 1981) belong to linguistic practices of urban youth communities and their (sub)cultures (e.g. Rampton 1995, 2006, Jørgensen 2005, Jørgensen and Qvist 2007, Keim 2007, Deppermann 2007, Qvist 2008, Lehtonen 2006, 2009 and forthc., Svendsen and Røyneland 2008).

But are these practices appreciated as instances of plurilingualism? Even today, attitudes towards language and style mixing tend not be positive, not even among language specialists. Monolingual ideals dominate and a wide repertoire of spoken language varieties is not considered to be especially valuable in our Western societies. Moreover, the use of several languages and resorting to one's native language in a FL classroom is interpreted as lacking proficiency (i.e. it is labeled as a communication strategy). The use of oral and non-standard varieties in school essays is often considered as a sign of an inability to master the standard language and literary registers, regardless of the stylistic of pragmatic functions of these varieties in their actual contexts, and the use of several languages in everyday situations or in the discourse of popular/ youth culture is considered to be bad or inferior language.

This could lead to a long discussion on the implementation of the recommendations concerning plurilingualism in the CEFR or address the specific problems of language education, e.g. the question of plurilingualism and teacher education or curriculum development in respect to plurilingualism (Kramsch et al. 2008). This however, is not the aim of my article. Instead, I will devote the rest of this article to discuss what would it mean to take seriously individual's linguistic repertoire and the functions of the different varieties in interaction and identity-work. For this purpose, I will present the reader with some examples of the Finnish L2 data from different contexts.

\section{Plurilingual practices and language proficiency: a look at data}

My first example comes from a classroom situation and it is relatively straightforward. The speaker B is a student of Finnish attending an elementary course in Finnish at a North-American 
university. $\mathrm{B}$ is speaking with a teaching assistant $\mathrm{O}$, who is a native speaker of Finnish. A quick glance at this example probably would lead us to interpret the situation as a typical case where the language learner is lacking words in the target language and thus resorts to his L1 as a communication strategy.

\author{
(1) \\ O: onko se kaunis kaupunki? \\ is it a beautiful town? \\ B: $\quad k y l l a ̈$ \\ yes \\ O: yhym \\ yhym \\ B: winatshi on (.) apple capital \\ winatshi is (.) apple capital \\ O: ahaa \\ oh \\ B: ja prozac capital \\ and the prozac capital \\ $\mathrm{O}$ : hehhee molemmat. mi(h)ks(i) hee \\ hehhee both. wh(y) hee \\ B: $\ddot{a} \ddot{a} m$ \\ ääm \\ O: $\quad$ miksi se on prozac capital hehee \\ why it is the prozac capital hee \\ B: ihmiset on (2) crazy \\ people are (2) crazy \\ O: hulluja \\ crazy (Kuisma 2001)
}

B's last turn ihmiset on (2) crazy can indeed be interpreted as an instance of a communication strategy. Here the English expression crazy is preceded by O's question after which B begins producing his answer in Finnish, and the English word is preceded by a two-second pause. A's reaction on the next line, hulluja, shows that she interprets B's expression, crazy, as a communication strategy and serves as the Finnish equivalent for A's English word as a repair for A's original turn.

But B's earlier English expressions in this extract, apple capital and prozac capital, do not invite A's repair turn. In fact, it would be extremely strange if they would. There is nothing to 
repair in B's turns because B exploits here the two participants' shared linguistic resources which include (elementary) Finnish and English.

Switching language functions here as a contextualization cue in the sense of Gumperz (1982, see also Auer 1992). Here English is used to introduce polyphony into the conversation. The expression apple capital clearly comes from (tourist) advertising discourse; it is not B's own voice that we hear but rather, following Bakhtin (1981), we could speak of double-voicing in service of an ironic effect. This use of another's voice to produce irony is then further elaborated by B as he forms the expression prozac capital. It seems that $\mathrm{O}$ does not quite follow this ironic tone, as she asks her why-question, miksi se on prozac capital hehee.

This example illustrates why it is misleading to judge any digression from L2 to L1 as compensatory or as a learner language phenomenon. Choosing le mot juste in the right context is not solely the privilege of a native or near-native speaker. Indeed all languages and linguistic varieties belonging to the participants' joint pool of linguistic resources can be taken into use during interaction. Of course, these languages and varieties need not be exploited. It may also happen, that the other participants do not recognize contextual cues which signal a change of footing (Goffman 1981) or another voice, and do not for instance, grasp the speaker's irony, but one has to bear in mind that these things also happen in monolingual conversations between native speakers. The ludic function of language belongs to all language use, to different stages of language acquisition and learner language (Hymes 1972b, Cook 2000, Broner and Tarone 2001).

Classical cases that rely upon the native-speaker to solve a communication problem need not only be interpreted as a non-native speaker's failed attempts to keep the conversation monolingual. An alternative interpretation recognizes that a situation in which the native speaker provides the missing words to the non-native speaker can develop into a pattern which enables their interaction to proceed smoothly. Both participants know the game - and several languages are simultaneously on the "desktop of the conversation".

My next example consists of two extracts from the same conversation that illustrate this. Here we have again two participants talking. One speaker is a language teacher A, and she 
is interviewing a (German-speaking) Swiss student (J) after a Finnish lesson. J seems to be missing words throughout the conversation. Nevertheless, their interaction continues smoothly. A recurring pattern in this conversation is the following: $\mathrm{J}$ utters an English expression, and A gives the Finnish equivalent in the following turn (few 'muutama', put the nets down' 'laskemme verkot'). Sometimes, however, more work is needed. In the same conversation but apparent in these extracts, A, for example, first asks a question and then quickly draws a picture of a ship in order to present $J$ the correct meaning of the Finnish word she has used in her question. Even this episode, in which a physical object is needed to reach a joint interpretation of A's question, is embedded in a smooth flow of interaction. But the speakers' common resources do not always match: throughout the conversation English is used as the speakers' shared interactional resource. $A$ and $J$ have different linguistic backgrounds and they are using English with different language inferences ${ }^{4}$. In this extract, $\mathrm{J}$ is searching for a Finnish equivalent for the compound coast guard. It seems that this English expression is unknown to A and $\mathrm{J}$ has to produce an extended paraphrase which finally leads to the correct interpretation. This example illustrates the complexity of the idea of shared linguistic resources and plurilingualism in practice. Things do not always run smoothly and one cannot rely on the both participants' knowledge of the supposed lingua franca. The dynamics of interaction therefore force participants to exploit a wide repertoire of linguistic resources even within the same conversation. In a NS-NNS conversation, this also implies that the roles of the informed and less-informed participant may be reversed from time to time.

A: $\quad$ tunnetko (0.2) onko sinulla jo monta ystävää (.) koulussa $\mathrm{J}$ : joo minulla on ${ }^{\circ} \mathrm{few}{ }^{\circ}$ ?

A: ${ }^{\circ}$ muntamia ${ }^{\circ}$

$\mathrm{J}: \quad$ imuntamia ${ }^{\circ}$ stavä (.) ystävää (.) ja: minulla on hyvä ystävä hän on (.) hän on Risto (.) kakskymmentä kaks ja hän on (.) coastguard? 'en tiedä suomeksi ${ }^{\circ}$ coastguard?

\section{A: coastguard?}

\footnotetext{
3 Notice that $\mathrm{J}$ is using here a non-idiomatic expression (put the nets down instead of cast the nets).

${ }^{4}$ I thank Kate Moore for emphasizing this point.
} 
$\mathrm{J}: \quad$ joo (0.2) hän on hän on työssä merissä ja hän [katsoo Venäjä

A:

[ahaa rannikkovartija

$\mathrm{J}: \quad$ joo rannikkovartija

A: ${ }^{\circ}{ }^{\circ o o j o o}{ }^{\circ}$

A: $\quad$ miten te kalastatte (.) ongella vai

J: joo me $<$ kalas(-)me $>(0.2)$ with nets?

A: ahaa verkoilla

$\mathrm{J}: \quad$ jo: verkoilla (.) ja me olemme illalla ä: meri ja (.) $>$ put the nets down< (0.2) äm:

A: laskemme verkot

$\mathrm{J}: \quad$ joo (.) ja menemme kotiin ja nuku (.) nukumme ((nukkumista os. ele)) ja (0.2) ilmalle? >in the morning $<$

A: aamulla

$\mathrm{J}: \quad$ aamulla $()>$. aamulla $<$ (.) menemme meriin (.) taas ja ää: [otam

A: [nostamme verkot

$\mathrm{J}$ : joo se on $>$ hyvin hauskaa $<$

Translation (2)

A: do you know (0.2) do you have many friends at school

$\mathrm{J}$ : yeah $\mathrm{I}$ have a ${ }^{\circ} \mathbf{f e w}{ }^{\circ}$

A: $\quad{ }^{\circ} \mathrm{Some}{ }^{\circ}$

$\mathrm{J}$ : $\quad$ Some friend (.) friends (.) and I have a good friend he is (.) Risto (.) twenty-two and he is (.) coastguard? I do not know in Finnish coastguard?

A: coastguard?

$\mathrm{J}$ : yeah (0.2) he is he is working in the sea and he [watches Russia

A:

$\mathrm{J}: \quad$ yeah coastguard

[ooh a coastguard

A: ${ }^{\circ}$ yeah yeah ${ }^{\circ}$

A: how do you fish (.) with an angle or

$\mathrm{J}$ : $\quad$ yeahwe $<$ fish $>(0.2$.) with nets?

A: oh with nets

$\mathrm{J}$ : yeah with nets and we are in the evening eh sea and >put the nets down $<$ ? $(0.2)$ ehm

A: put the nets down 
J: $\quad$ yeah (.) and we go home and sleep (.) we sleep

((gesture expressing sleeping)) and (0.2) to the air? in the

\section{morning}

A: $\quad$ in the morning

$\mathrm{J}$ : $\quad$ in the morning (.) $>$ in the morning $<$ (.) we go to the sea (.) again and ee- we take

A: take up the nets

$\mathrm{J}$ : $\quad$ yeah it is $>$ great fun $<$

The previous example illustrates the dilemma about the relationship between language proficiency and plurilingualism. The monolingual perspective to language learning obviously sees the goal for language acquisition and language teaching as proficiency in the "target language". The plurilingual perspective, on the other hand appreciates participants' skills in using all their linguistic resources, i.e. the optimal use of the available linguistic varieties to ensure smooth interaction (see also Kalliokoski 2009).

An important component of communicative competence, also for L2 speakers is the knowledge of different varieties within one language and their different potential as interactional resources, i.e. knowledge about to whom they "belong". The next example comes from a situation where a Finnish student $\mathrm{H}$ is interviewing A, a Vietnamese speaker (taped in the late 1980s). Here A uses learner Finnish, and follows closely the written Standard Finnish model, whereas H's speech could be characterized as average spoken Finnish. These different standards collide in their dialogue several times during the short extract particularly in their subject-verb concord. But instead of focussing on the grammar and the speakers' chosen varieties I would like to draw the reader's attention to the style shifting which takes place in A's turns towards the end of the extract. Suddenly, in the middle of his standard/learner language turn, A produces the slang characteristic of Helsinki youth. This slang is clearly not part of A's own linguistic repertoire but belongs to somebody else. Young people with a xenophobic attitude are depicted in A's narrative by using their own words. As, for instance, Gumperz (1982) has shown, code-switching often occurs in quotations. Here, however, A is not merely quoting someone: the slang expression souta himaan ${ }^{5}$ is clearly presented as "their" language, as a stylistic resource

\footnotetext{
${ }^{5} \mathrm{NB}$ : A's souta himaan is not quite correct as a slang expression. The imperative form requires consonant gradation: souda himaan.
} 
used to portray xenophobic discourse, obviously not belonging to A's own stylistic repertoire:

(3)

$\mathrm{H}$ : olet sä, olet sä itse törmännyt sellasiin ihmisiin jotka ei pidä ulkomaalaisista, Suomessa?=

A: $\quad=$ joo, sitä on ollut esime- minun asupai- asuu- aa- asuupaikkani niinku siellä, nuoriso eivät, ee ei ei pitävät, ulkomalaisista.

$\mathrm{H}: \quad$ onk + se $>$ nimenomaan $<$ vain nuoret ihmiset?

A: joo nimenomaan nuoret ihmiset, ne eivät, pitäneet ul-ulkomaalaisista

[paitsi ] niinku, meistä pakolaisesta, $\$ \$$

$\mathrm{H}: \quad$ [millä-,] millä tavalla ne näyttää sen?

A: ne näyttävät keskiSORmi ja sanovat meille että souta himaan, (2)

$\$$ sillä tavalla niinku $\$=$

$\mathrm{H}: \quad=$ mitä sanovat?

A: $\quad$ souta himaan, \$ souta himaan \$ elikkä tulemme, ((vetää henkeä)) ja joskus minä vastaan sinne et-, niinko heille että minä tulen Suomeen lentokoneella, ei voi souta himaan niinku, pienilä veneilä kotii(n).

Translation (3)

$\mathrm{H}$ : have, have you yourself bumped into the kind of people who don't like foreigners, in Finland?=

A: $\quad=y e a h$, there have been, for examp- my neigh- nee- neighbourhood like there, young people do not, ee, not like, foreigners

$\mathrm{H}: \quad$ is it $>$ particularly $<$ only young people?

A: yeah particularly young people, they didn't like fo- foreigners [except] like, us refugees $\$$

$\mathrm{H}$ : [how-] how do they show it?

A: they give (you) the (middle)FINger and tell us to row home (2) that's how like $\$=$

$\mathrm{H}$ : = what (do they) say?

A: row home $\$$ row home that is we come ((draws breath)) and sometimes I answer there tha- like to them that I come to Finland by plane I cannot row home like on small boats to home

\footnotetext{
${ }^{6}$ The symbol $\$$ indicates smiling voice (laughter).
} 
Learning to keep apart oral and written varieties is something which takes place during formal school education. Recently, Mia Halonen (2009) has demonstrated how adolescents with immigrant backgrounds manage to keep these two modes apart and use both as resources in different genres and for different audiences. She tested the oral and written skills of sixth-grade (12-year-old) pupils. One of the tasks on her test was to write two letters, one formal and one informal. The formal letter was to address the school headmaster and one letter was to address a friend on the same topic (family trip to Spain). Halonen's data show that even those writers who do not succeed so well in producing written Standard Finnish clearly have a conception of these different varieties and try to keep apart the features of oral and written discourse or slang and standard language in their texts (cf. also Kalliokoski 2008).

Plurilingual speakers can also use those linguistic varieties that combine several other varieties and layers of elements originating from other languages and varieties. These kinds of hybrid varieties include (traditional) urban slang, and the varieties belonging to various subcultures (cf. Blommaert 2010, Pennycook 2010). One could perhaps speak of layered or secondary plurilingualism when referring to adolescents with immigrant backgrounds performing hiphop in their L2, or to cases when a L2 speaker is using the local - or rather glocal - slang in his/her speech or writing.

The author of the text in example 4 is a 16-year-old pupil at Finnish secondary school ( $9^{\text {th }}$ grade). The text is from a pilot of a national test for ninth-grade pupils. The assignment was to write about a hero. This passage contains features of learner Finnish that are combined with a good command of Helsinki youth slang.

In the late 19th century and during the first decades of the $20^{\text {th }}$ century, Helsinki slang contained lexical items from Swedish, Russian and Finnish as well as from German and Yiddish. Today, however, Helsinki slang imports most of its "foreign" elements from English, especially from the language of youth subcultures. The "foreign" elements in this text are easy to notice (indicated in bold face). However, it would be incorrect to interpret them as instances of code switching. These expressions (bisnes, boss, rannas) are all codified slang words: they are included in the Helsinki slang dictionary by Paunonen published in 2000. The L2 writer 
thus uses his knowledge of slang as a resource for creating a tough adventure story. The overall style of this written story is a result of various plurilingual layers embedded in the slang itself (secondary plurilingualism?) and of the author's multilingual background and learner language features. Notice that we can even trace elements of Swedish in the text: the verb hogasi 'remembered' has its etymology in the Swedish komma ihåg.

\section{(4) Kalle-story}

Olipakerran Kalle meni matkalle kiinaan. Hän meni tekemään bisnestä Kiinan kanssa. Sitten hän meni hotelliin. Sitten Kalle meni huoneseen ja makasin sängyyn. Sitten hän nukui. Kun Kalle heräsi sitten hän meni ulos syömään. Hän meni ravintolalle syömään. Kun hän on syönyt, Kalle meni lenkeilylle, mutta kesken matka hän näki kaunis muija joka käveli häntä ohi. Kalle kuolasi sitten kun hän käänsi takasin päin niin hän pää kolahti suoraan puuhun. Kun Kalle heräsi hän oli sairaalassa. Hän kysyi sairaan hoitajalta "Missä minä olen". Sairaan hoitaja vastasi "sinä olet sairaalassa" Kalle kysyi "miksi olen sairaalassa". Hoitaja vastasi "sinä kolahti pää pu[u]hun ja kaksi neiti toi sinut tänne sairaalaan". Sitten Kalle hogasi että hänellä on tanään bisnestä. Kalle soitti Suomeen hänen bossille ja sanoi "anteeksi minä en voi tänään tekee sen bisnestä koska minä olen sairaallassa”. Kun Kalle bossi kuuli vähä bossi kiljuu. Sitten boss paiskasi luuri täysillä kiinni. Kun Kalle pääsi sairaalasta pois Kalle meni hotelliin ja meni huoneeseen. Kallella oli kauhee väsynyt. Hän nukui. Kun hän näki unta hän heräsi heti ja juoksi ulos huoneesta ja meni missä hän lähti lenkeili viimeksi. Hän juoksi ympäri koko puisto, mutta ei silti löytänyt se muija ketä hän viimeksi näen. Kalle ei ollut iloinen hän lähti takaisin hotelliin sitten Kalle näki se muija joka hän näki viimeksi. Sitten Kalle huusi "Hei neitti" Kaikki katsoi Kalle päin. Vähä Kalle oli noloo kun hän viellä hyppä siinä, mutta muija ei nähnyt.

Kaikki kyylää Kalle sitten hän rannas täysillä huoneeseen. Kaksi viikko sitten Kalle meni ostoksille ja hän putosi lompakonsa, mutta Kalle ei huomaa. Kun Kalle otti kamansa kassaan. Hän alkaa penkoo rahat, mutta ei löytänyt lompakonsa. Kalle kävi tu[u]ri, neitti sanoi "hei äijä sinä tippui lompakonsa". Kalle sanoi "Kiitos kun löysit minun lompakonsa". Sitten hän lähti kaupasta. Kalle käveli vähän matkan sitten hän näki sen muija Kalle jätti 
kaikki ruokka ja juoksi sitä muija perään. Kun Kalle näki sen muijalla on jo mies. Kalle ei ollut iloinen. Ja Kalle meni takaisin hotelliin ja hogasi että hänen kamat jätti kadulle hän huusi sen jälkeen täysillä “voi ei !!!!!”. Hän palasi takaisin Suomeen ja meni duuni paikalle. Ja meni bossin huoneen ja boss vinkui kuin sika.

\section{THE END}

Once upon a time Kalle went on a trip to China. He went to do business with China. Then he went to a hotel. Then Kalle went to his room and laid down on the bed. Then he slept. When Kalle woke up then he went out to eat. He went to a restaurant to eat. When he had eaten, Kalle went jogging but in the middle of his course he saw a beautiful chick who walked towards him. Kalle was slothering then when he turned around he head crashed straight into a tree. When Kalle woke up he was in hospital. He asked a nurse "Where am I?" The nurse answered: "you are in hospital" Kalle asked "why am I in hospital?" The nurse answered "you crashed your head into a tree and two ladies brought you here to the hospital". Then Kalle remembered that he had today business. Kalle called Finland to his boss and said "I am sorry I cannot do business today because I am in hospital". When Kalle('s) boss heard he screamed a lot. Then the boss banged the receiver down. When Kalle got out of hospital Kalle went to a hotel and went to the room. Kalle was terribly tired. He slept. When he dreamt he woke up at once and ran out of the room and went where he had been jogging last. He ran around the whole park, but did not find the chick whom he had seen the last time. Kalle was not happy he went back to the hotel then Kalle saw that chick whom he saw last time. Then Kalle shouted "Hi Miss". Everybody was watching Kalle. He was really embarassed when he still was jumping there but the chick was not to be seen.

Everybody stares at Kalle then he ran full speed to the room. Two weeks ago Kalle went shopping and he dropped his wallet but Kalle doesn't notice. When Kalle took his stuff at the pay-desk. He starts looking for the money but he did not find his wallet. Kalle was lucky, the Missis said "hey old man you dropped his wallet". Kalle said: "Thanks for finding my wallet." Then he left the shop. Kalle walked a while then he saw the chick Kalle left all his food and ran after the chick. When Kalle saw 
her the chick already had another man. Kalle wasn't happy. And Kale went back to the hotel and remembered that he left his stuff in the street and shouted then out loud "oh no!!!" He returned to Finland and went to his working place. And he went to the boss's room and the boss yelled like a pig.

THE END

\section{Conclusions}

Hymes' notion of communicative competence originally included plurilingualism. In addition, the plurilingual individual and his/her varying competence in different languages and in different linguistic varieties are the focus of the (socio)linguistic research programme presented in Hymes's article. Hymes does not actually use the term plurilingual competence. One of the reasons for this might be that his programme was a reaction to Chomsky's (1965) dichotomy competence - performance and the notion of ideal speaker-hearer. When discussing - and rejecting - Chomsky's conception of competence Hymes had no need to address issues such as multilingualism or plurilingualism. Chomsky's view on language was strictly monolingual. When presenting and illustrating communicative competence, Hymes does not make a distinction between an L1 and an L2 - his view of language and communicative competence encompassed language of all varieties.

Even though the concept of communicative competence was quickly adopted to applied linguistics, the idea of a linguistic repertoire consisting of the competencies of several languages and varieties was not imported to the realms of SLA or language testing. The Hymesian perspective to plurilingualism as an essential dimension of communicative competence was revived in the Common European Framework (CEFR). However, the practice of applying the CEFR in different contexts has mostly neglected the dimension on plurilingualism and plurilingual competence. The focus in the use of the CEFR and its functionally motivated taxonomies has been on the different areas of language skills (speaking, writing, reading comprehension, etc.) within one single language at a time, while the application of plurilingual practices in language education, curriculum planning and language testing has gained very little attention. 
Promotion of plurilingualism as a resource for language use presents a challenge for language education. Kramsch and Whiteside (2008) propose a theory of "symbolic competence" in order to describe language use in a multilingual setting. Their ecological approach to language combines the study of multicultural individuals and their linguistic practices to such notions as subjectivity, historicity and cultural memories. The proposal by Kramsch and Whiteside, together with the previously mentioned recent contributions by other scolars of plurilingualism and language pedagogy (Kramsch et al. 2008, Lüdi and Py 2009, Moore and Gajo 2009), represent a serious project aiming at a true implementation of plurilingualism and plurililingual competence (such as they are stated, for instance in the CEFR) in language education.

The Hymesian notion of communicative competence has lived on and developed in the sociolinguistic research tradition, especially within interactional sociolinguistics. The study of linguistic practices in multilingual communities has taught us to appreciate plurilingual competence as an interactional resource and as a part of language users' identities. This dynamic and context-sensitive view to plurilingualism and linguistic variation has an obvious connection to Hymes's original idea about communicative competence. From the perspective of language learning, plurilingual competence enables speakers with different linguistic backgrounds to use their shared linguistic repertoire in order to ensure smooth interaction.

Apart from the referential function of language, plurilingual competence serves interpersonal, emotional, poetic and textual functions. The shared (or assumedly shared) plurilingual competence is used to produce hetereglossia in discourse and to guide the participants' interpretations of changes in the context (contextualization). Thus plurilingual competence functions as a powerful resource for constructing new (g)local identities in our changing globalized world.

\section{Address:}

Jyrki Kalliokoski

Suomen kielen, suomalais-ugrilaisten ja pohjoismaisten kielten ja kirjallisuuksien laitos

Fabianinkatu 33 (5. krs)

PL 3, 00014 Helsingin yliopisto

E-mail: jyrki.kalliokoski@helsinki.fi 


\section{References}

Androutsopoulos, Jannis (2007) "Style online: doing hip-hop on the Germanspeaking Web". In Peter Auer, ed. Style and social identities: alternative approaches to linguistic heterogeneity, 279-317. Berlin and New York: de Gruyter.

Auer, Peter (1992) “Introduction: John Gumperz's approach to contextualization". In Peter Auer and Aldo di Luzio, eds. The contextualization of language, 1-37. Amsterdam: John Benjamins.

Auer, Peter (ed.) (2007) Style and social identities: alternative approaches to linguistic heterogeneity. Berlin: Mouton de Gruyter.

Auer, Peter and Li Wei (2007) "Multilingualism as a problem? Monolingualism as a problem?". In Peter Auer and Li Wei, eds. Handbook of multilingualism and multilingual communication, 1-12. Berlin: Mouton de Gruyter.

Bachman, Lyle F. (1990) Fundamental considerations in language testing. Oxford: Oxford University Press.

Bakhtin, Mikhail M. (1981) The dialogic imagination: four essays. Michael Holquist, ed. Austin: University of Texas Press.

Blommaert, Jan (2010) The sociolinguistics of globalization. Cambridge: Cambridge University Press.

Broner, Maggie A. and Elaine E. Tarone (2001) "Is it fun? Language play in a fifth-grade Spanish immersion classroom”. The Modern Language Journal 885, iii, 363-379.

Campbell, Robin and Roger Wales (1970) "The study of language acquisition”. In John Lyons, ed. New horizons in linguistics. Harmondsworth, Middlesex: Penguin Books.

Canale, Michael and Merrill Swain (1980) "Theoretical bases of communicative approaches to second language teaching and testing". Applied Linguistics 1, 1, 1-147.

Canale, Michael (1983) "From communicative competence to communicative language pedagogy”. In Jack C. Richards and Richard W. Schmidt, eds. Language and communication, 2-27. London: Longman.

CEFR = Common European Framework for Languages: Learning, teaching and assessment. $<$ http://www.coe.int/t/dg4/linguistic/Source/Framework _EN.pdf $>$. Accessed 28 June, 2011.

Chomsky, Noam (1965) Aspects of the theory of syntax. Cambridge, MA: MIT Press.

Cook, Guy (2000) Language play, language learning. Oxford: Oxford University Press.

Coste, Daniel, Danièle Moore, and Genevieve Zarate (1997) Plurilingual and pluricultural competence. Council of Europe. http://www.coe.int/t/dg4/ 
linguistic/Source/SourcePublications/CompetencePlurilingue09web_ en.pdf

Deppermann, Arnulf (2007) "Playing with the voice of the other: Stylized Kanaksprak in conversations among German adolescents". In Peter Auer, ed. Style and social identities: alternative approaches to linguistic heterogeneity, 325-360. Berlin and New York: de Gruyter.

Eckert, Penelope and John R. Rickford, eds. (2001) Style and sociolinguistic variation. Cambridge: Cambridge University Press.

Goffman, Erving (1981) Forms of talk. Philadelphia: University of Pennsylvania Press.

Gumperz, John J. (1982) Discourse structures. Cambridge: Cambridge University Press.

Gumperz, John J. (1992) “Contextualization revisited”. In Peter Auer and Aldo di Luzio, eds. The contextualization of language, 39-53. Amsterdam: John Benjamins

Halonen, Mia (2009) "Puhutun kielen variantit resurssina monikielisten koululaisten kirjoitelmissa”. (Summary: Variants of spoken language as a resource in essays by multilingual schoolchildren.) Virittäjä 113, 3, 329-355.

Hymes, Dell (1972a) “On communicative competence”. In John B. Pride and Janet Holmes, eds. Sociolinguistics, 269-293. Harmondsworth: Penguin Books.

Hymes, Dell (1972b) "Models of interaction of language and social life”. John. J. Gumperz and Dell Hymes, eds. Directions in sociolinguistics, 35-71. New York: Holt, Rinehart and Winston.

Jørgensen, Jens Normann (2005) "Plurilingual conversations among bilingual adolescents". Journal of Pragmatics 37, 391-402.

Kalliokoski, Jyrki (2008) "Developing writing skills in the majority language". In Johanna Laakso, ed. Ungarischunterricht in Östrreich. Perspektiven und Vergleichspunkte, 115-127. (Finno-Ugrian Studies in Austria, 6.) Wien: LIT.

Kalliokoski, Jyrki (2009) "Koodinvaihto ja kielitaito". In Jyrki Kalliokoski, Lari Kotilainen, and Päivi Pahta, eds. Kielet kohtaavat, 309-330. Helsinki: Suomalaisen Kirjallisuuden Seura.

Keim, Inken (2007) "Socio-cultural identity, communicative style, and their change over time: a case study of a group of German-Turkish girls in Mannheim/Germany". In Peter Auer, ed. Style and social identities: alternative approaches to linguistic heterogeneity, 155-186. Berlin and New York: de Gruyter.

Kuisma, Karoliina (2001) "Alkeisoppijan kommunikaatiostrategiat puheessa ja kirjoitelmissa: kielelliset ongelmatilanteet ja niistä selviytyminen”. 
In Taija Nieminen, ed. Vuorovaikutus ja suomen kielen oppiminen, 11-75. (Kakkoskieli, 3.) Helsinki: Helsingin yliopiston suomen kielen laitos.

Kramsch, Claire and Anne Whiteside (2008) "Language ecology in multilingual settings: towards a theory of symbolic competence". Applied Linguistics 29, 4, 645-671.

Kramsch, Claire, Danielle Lévy, and Geneviève Zarate (2008) "Volume conclusion”. In Zarate, le Lévy \& Kramsch. < http://precis.berkeley.edu/index. php/Volume_Conclusion>.

Lehtonen, Heini (2006) "Maahanmuuttajanuoret plurilingvaalisuuden mannekiineina”. Salla Kurhila and Anne Mäntynen, eds. Tunnetta mukana, 13-29. (Kieli, 17.) Helsinki: Helsingin yliopiston suomen kielen ja kotimaisen kirjallisuuden laitos.

Lehtonen, Heini (2009) "Maahanmuuttajataustaisten helsinkiläisnuorten monikielisyyden ilmiöitä”. In Jyrki Kalliokoski, Lari Kotilainen, and Päivi Pahta, eds. Kielet kohtaavat, 161-190. Helsinki: Suomalaisen Kirjallisuuden Seura.

Lehtonen, Heini (forthc.) "Developing multiethnic youth language in Helsinki". Ms., submitted for publication.

LePage, Robert Brock, Andrée Tabouret-Keller (1985) Acts of identity: creolebased approaches to language and ethnicity. Cambridge University Press: Cambridge.

Lüdi, Georges and Bernard Py (2009) "To be or not to be ... a plurilingual speaker". International Journal of Multilingualism 6, 2, 154-167.

Moore, Danièle and Laurent Gajo (2009) "Introduction - French voices on plurilingualism and pluriculturalism: theory, significance and perspectives". International Journal of Multilingualism 6, 2, 137-153.

Paunonen, Heikki (2000) Tsennaaks Stadii, bonjaaks slangii. Stadin slangin suursanakirja. Werner Söderström Osakeyhtiö: Helsinki.

Pennycook, Alastair (2010) Language as a local practice. Routledge: London.

Rampton, Ben (1995) Crossing. Language and ethnicity among adolescents. Longman London.

Rampton, Ben (2006) Language in late modernity. Interaction in an urban school. Cambridge: Cambridge University Press.

Qvist, Pia (2008) "Sociolinguistic approaches to multiethnolect: Language variety and stylistic practice". International journal of Bilingualism 12, 1-2, 43-61.

Qvist, Pia and Jens Normann Jørgensen (2007) "Crossing - negotiating social boundaries". In Peter Auer and Li Wei, eds. Handbook of multilingualism and multilingual communication, 371-389. Berlin: Mouton de Gruyter.

Svendsen, Bente Ailin and Unn Røyneland (2008) "Multiethnolectal facts and 
functions in Oslo, Norway". International journal of Bilingualism 12, $1 \& 2,63-83$.

Zarate, Geneviève, Danielle Lévy, and Claire Kramsch (2008) eds. Précis $d u$ plurilinguisme et du pluriculturalisme. Éditions des archives contemporaines: Paris. English version under construction: <http://precis. berkeley.edu/index.php/Main_Page>. Accessed 28 June, 2011.

Kokkuvõte. Jyrki Kalliokoski: Paljukeelne kompetents, stiilid ja varieerumine. Artiklis käsitletakse paljukeelset kompetentsi (plurilingual competence) seoses keeleoskuse, keeleõppe ning palju- ja mitmekeelsusega. Kommunikatiivse kompetentsi mõiste pärineb Hymes'ilt (1972) vastusena Chomsky nägemusele keelest kui autonoomsest süsteemist. Hymes'i nägemus kommunikatiivsest kompetentsist sisaldas algselt ka paljukeelsust. Kommunikatiivse kompetentsi mõiste võeti rakenduslingvistikas kiiresti omaks, kuid mitmetest keelevariantidest koosneva keelelise repertuaari idee ei jõudnud teise keele õppesse ja keeletestidesse. Hymes'i nägemus paljukeelsusest kui kommunikatiivse kompetentsi loomulikust osast taaselustus Euroopa Keeleõppe Raamdokumendis (CEFR). Ometi pole Euroopa Keeleõppe Raamdokumendi rakendamisel paljukeelsusele ja paljukeelse kompetentsi mõõtele eriti tähelepanu pööratud. Fookuses on hoopis keeleoskuse erinevad aspektid ühe keele puhul korraga, samal ajal kui paljukeelsete praktikate kohandamine on pälvinud vähe tähelepanu. Hymes'i kommunikatiivse kompetentsi idee on edasi elanud sotsiolingvistika uurimistraditsioonis, eriti suhtlusuuringutes. See artikkel seob Hymes'i paljukeelse kompetentsi algidee paljukeelsuse ja paljukeelse hariduse praeguste trendide ning sotsiolingvistiliste stiili- ja keeleliste varieteetide uuringutega mitmekeelsetes kogukondades. Artiklis on kasutatud soome keele teise keelena ainestikku näitamaks, kuidas paljukeelne kompetents suhtlusvahendina rakendust leida võib. Keeleõppe seisukohalt võimaldab paljukeelne kompetents erineva keelelise taustaga kõnelejatel kasutada oma jagatud keelelist repertuaari tagamaks sujuvat suhtlust ning vastastikkust arusaamist.

Märksõnad: kommunikatiivne kompetents, paljukeelsus, keeleõpe, suhtlemine 